\title{
Spraakklankdistorsie by Neuromotoriese Spraakafwykings: 'n Vergelyking tussen Serebellêre Disartrie en Verbale Apraksie
}

\author{
Isna Erasmus \\ Anita van der Merwe \\ Emily Groenewald \\ Departement Spraakheelkunde en Oudiologie \\ Universiteit van Pretoria
}

\begin{abstract}
OPSOMMING
Spraakklankdistorsie word algemeen in die literatuur beskryf as 'n kenmerk van neuromotoriese spraakafwykings soos serebellêre disartrie en verbale apraksie. Die doel van die studie is ' $n$ vergelykende ondersoek na die temporale en ruimtelike aspekte van spraakklankdistorsie by twee persone met verworwe serebellêre disartrie en een persoon met verworwe verbale apraksie. Die spraakparameters stemaanvangstyd van die [d], afsluitingsduur van die [d], konsonantduur van die [s] en [l], formante van die [l] en die omvang van akoestiese energie van die [s], is spektrografies ondersoek in ' $n$ aantal uitinge met verskillende klankstrukture. Die resultate dui daarop dat ruimtelike en temporale distorsie van artikulatoriese bewegings voorkom by die proefpersone met serebellêre disartrie sowel as by die proefpersoon met verbale apraksie. Daar is egter verskille opgemerk in die aard en graad van die spraakklankdistorsie by die onderskeie afwykings. Die teoretiese implikasies van hierdie verskille word bespreek met verwysing na' $n$ model van normale spraakproduksie.
\end{abstract}

\begin{abstract}
Speech sound distortion is considered to be a salient feature of neuromotor speech disorders such as cerebellar dysarthria and apraxia of speech. The aim of this study was to compare the temporal and spatial aspects of speech of two persons with acquired cerebellar dysarthria and of one person with acquired apraxia of speech. Voice onset time of [d], duration of articulatory closure of [d], duration of [s] and [l], formants of $[l]$ and the range of acoustic energy of [s] were analysed spectrographically in a number of utterances with various sound structures. The results indicated that spatial and temporal distortion of articulatory movements occurred in all three subjects. However, differences in the nature and degree of speech sound distortion in the two different disorders were observed. The theoretical implications of these differences are discussed with reference to a model of normal speech production.
\end{abstract}

Spraakklankdistorsie word algemeen in die literatuur beskryf as 'n kenmerk van neuromotoriese spraakafwykings soos serebellêre disartrie en verbale apraksie (Brown, Darley \& Aronson, 1970; Kent, Netsell \& Abbs, 1979; Itoh \& Sasanuma, 1984; Hardcastle 1987; Odell, McNeil, Rosenbek \& Hunter, 1990; Odell, McNeil, Rosenbek \& Hunter, 1991). Serebellêre disartrie en verbale apraksie is egter die resultaat van die aantasting van verskillende neurale dele, wat betrokke is by verskillende stadiums of fases van die spraakproduksieproses. Verbale apraksie word tradisioneel gesien as 'n afwyking in spraakprogrammering terwyl disartrie getipeer word as 'n afwyking in die uitvoering van spraakbewegings. Daar is egter aanduidings in die literatuur dat serebellêre disartrie en verbale apraksie sekere ooreenstemmings toon in die aard van waargenome spraakklankdistorsies soos byvoorbeeld verlenging van woordsegmente, lettergreepspraak en temporale diskoördinasie van spraakstrukture wat by albei afwykings voorkom (Kent et al., 1979; Kent \& Rosenbek, 1982). Die rede hiervoor is onbekend. Vorige akoestiese studies aangaande verbale apraksie en serebellêre disartrie het slegs enkele aspekte soos vokaalformante en segmentele duur ondersoek en die vraag ontstaan presies watter temporale en ruimtelike aspekte van distorsie by die twee afwykings ooreenkom en verskil. 'n Omvattende, objektiewe akoestiese analise van verskillende fasette van spraakklankproduksie sal distorsie by hierdie afwykings verder toelig. Die presiese aard van spraakklankdistorsie kan aanduidings gee van die aard van die twee tipes neuromotoriese afwykings en ook lig werp op die bydrae van die kortikaal-motoriese dele en die serebellum tot die beheer van spraakbewegings.

Navorsing oor die spesifieke spraakkenmerke van serebellêre disartrie en verbale apraksie word hoofsaaklik gekenmerk deur twee eksperimentele ondersoekmetodes. Hierdie metodes behels subjektiewe metodes soos breë fonetiese perseptuele transkripsies en objektiewe metodes soos akoestiese analises, elektropalatografiese studies en fibroskopiese studies. Vroeë subjektiewe ondersoeke 
aangaande serebellêre disartrie is hoofsaaklik gerig op simptoombeskrywings. Op grond van subjektiewe perseptuele studies word die kenmerkende simptome van serebellêre disartrie in drie verbandhoudende hoofsimptoomgroepe verdeel, nl. simptome gekenmerk deur artikulatoriese onakkuraatheid bv. "onpresiese konsonante" en vokaaldistorsies, simptome gekenmerk deur prosodiese oormaat bv. oormatige en gelyke klem, verlengde foneme en stadige spraakspoed en simptome gekenmerk deur fonatories-prosodiese onvermoë bv. monotone spraak, monoluidheid en heesheid (Darley, Aronson \& Brown, 1969b; Brown et al.,1970). Grunwell en Huskins (1979) beklemtoon dat hierdie simptome van serebellêre disartrie deurlopend teenwoordig is en kumulatief van aard is. Hulle beskryf die kumulatiewe aantasting van spraakverstaanbaarheid as ' $n$ tekort aan intonasie en normale ritme met sogenaamde "scanning speech", verlengde konsonante, periodieke foutiewe stemgewing en nasaliteit as resultaat. Hierdie perseptuele simptoombeskrywings slaag egter nie altyd daarin om tussen verskillende tipes disartrie te onderskei nie (Zyski \& Weisiger, 1987) en die aard van die afwyking kom ook nie duidelik na vore nie.

Enkele ondersoeke met objektiewe analisemetodes soos akoestiese en kineradiografiese studies wat die aard van spraaksimptome by serebellêre disartrie beter toelig, is uitgevoer. Opsommend beskou, is die volgende waarnemings deur Kent en Netsell (1975) en Kent et al. (1979) gemaak : verlengde artikulatoriese beweging van die tong, geringe vokaaldistorsie weens swak anterior-posterior aanpassing van tongposisie, konstante onakkurate artikulasie van dorsale afsluitingsklanke, verlengde segmentduur, gelyke en oormatige klem, afwykende fundamentele frekwensiewaardes en variasie in fundamentele frekwensiewaardes. Vanuit hierdie resultate blyk dit dat spraakklankdistorsie 'n kernsimptoom is van serebellêre disartrie.

Studies oor die spraakkenmerke van persone met verbale apraksie is kontroversieel van aard, deels as gevolg van die kwessie van die ontledingsmetode. Aanvanklike studies aangaande verbale apraksie het hoofsaaklik gebruik gemaak van subjektiewe, perseptuele analiseprosedures soos distinktiewe eienskapsanalises en gemerktheidsanalises (Klich, Ireland \& Weidner, 1979). Op grond van hierdie resultate is die kernsimptoom van apraksie dan beskryf as vervangings. Nuwe navorsing deur middel van meer objektiewe studiemetodes soos akoestiese ontledings, getroue fonetiese transkripsies, en elektropalatografiese waarnemings dui egter daarop dat alhoewel ware klankvervangings ook deel vorm van die simptoomkompleks van verbale apraksie, baie van die "vervangings" wat in vroeë studies geïdentifiseer is, in werklikheid spraakklankdistorsies was (Itoh \& Sasanuma, 1984; Kent \& Rosenbek, 1983; Hardcastle, Morgan Barry \& Clark, 1985; Van der Merwe, Uys, Loots \& Grimbeek, 1988; Odell et al., 1990; Odell et al., 1991). Tans word dit algemeen aanvaar dat spraakklankdistorsie 'n kernsimptoom van verbale apraksie is.

Akoestiese studies van verbale apraksie en studies wat van direkte waarnemingsmetodes van die artikulators gebruik maak, verskaf direkte en meer presiese inligting aangaande afwykende motoriek. Uit hierdie studies kan 'n goeie aanduiding verkry word van spraakklankdistorsies by verbale apraksie en die motoriese prosesse daarby betrokke. Kent en Rosenbek (1983) gee 'n simptoombeskrywing van 'n verbaal-apraktiese spreker op grond van foute geïdentifiseer tydens akoestiese analises, nl. stadige spraakspoed met verlenging van klankoorgange, vermindering in intensiteitsvariasies oor sillabes heen, stadige en onakkurate beweging na ruimtelike teikens vir konsonant- en vokaalproduksie, probleme met tydsberekening en koördinasie van stemgewing met die beweging van ander artikulators, periodieke foute met segmentseleksie of opeenvolging en inisiëringsprobleme. Ander akoestiese ondersoeke van verbale apraksie bevestig die resultate van Kent en Rosenbek (1983) en vind byvoorbeeld ook afwykings in interartikulator-sinchronisasie en verlengde segmentele duur (Sands, Freeman \& Harris, 1978; Hardcastle, 1987; Itoh, Sasanuma, Tatsumi, Murakami, Fukusaki \& Suzuki, 1982; Collins, Rosenbek \& Wertz, 1983; Kent \& McNeil, 1987; Van der Merwe, Uys, Loots, Grimbeek \& Jansen, 1989).

Uit die voorafgaande literatuuroorsig is dit duidelik dat spraakklankdistorsie as kernsimptoom by sowel serebellêre disartrie as by verbale apraksie geïdentifiseer is, maar dat die aard van die spraakklankdistorsies nog nie genoegsaam uitgelig is nie. Vergelykende studies tussen verbale apraksie en serebellêre disartrie kan meer lig werp op die motoriese aard van moontlike ooreenkomste en verskille in die spraakklankdistorsies. Daar bestaan egter weinig sulke studies. In 'n resente perseptuele vergelykende ondersoek tussen serebellêre disartrie, verbale apraksie en konduksie-afasie deur middel van objektiewe, getroue fonetiese transkripsies is kortliks gevind dat die persone met verbale apraksie en serebellêre disartrie as 'n groep meer ooreenkomste toon met mekaar as met konduksie-afasie (Odell et al., 1991). Die verbale apraksie groep het egter minder distorsies vertoon as die serebellêre disartrie groep, nl. $64 \%$ teenoor $81 \%$, asook meer sillabeklemfoute en verlengings van intersegment klankoorgange. Geen aanduiding word egter verskaf van die bewegingsaspekte betrokke by die waargenome foute nie. Kent en Rosenbek (1982) vind in 'n vergelykende akoestiese ondersoek dat sprekers met verbale apraksie sowel as sprekers met serebellêre disartrie prosodiese afwykings soos artikulatoriese verlengings en sillabesegregrasie toon en verduidelik dit as die resultaat van kompensasie vir die neuromotoriese aantasting. Gillmer en Van der Merwe (1983) vind dat sowel sprekers 'met serebellêre disartrie as sprekers met verbale apraksie afwykende stemaanvangstydwaardes (SAT) vertoon en dat SAT-waardes meer gevarieer het vir die sprekers met serebellêre disartrie. Weens 'n tekort aan objektiewe vergelykende studies en die feit dat bestaande studies slegs enkele spraakparameters ondersoek het, is daar tans steeds ' $n$ tekort aan omvattende inligting betreffende die aard en omvang van spraakklankdistorsie by die onderskeie afwykings asook verklarings vir moontlike ooreenkomste.

Spraaksimptome soos spraakklankdistorsie wat na spesifieke neurale aantasting voorkom, kan gedeeltelik verklaar word aan die hand van kennis oor die funksie van die betrokke aangetaste neurale deel. Verbale apraksie en serebellêre disartrie verteenwoordig letsels in verskillende dele en op verskillénde vlakke van die brein. Serebellêre disartrie word met aantasting van die serebellum in verband gebring (Kent \& Netsell, 1975; Kent et al., 1979, Grunwell \& Huskins, 1979). Ten spyte van uitgebreide navorsing oor die funksies van die serebellum 
is daar egter steeds weinig bekend oor die rol daarvan in spraakmotoriek (Gentil, 1990). Posturale en neuromotoriese simptome geassosieer met serebellêre letsels, nl. asinergie, disdiadokokinese van spraakbewegings, intensietremor gedurende beweging en hipotonus van spiere lei tot die ruimtelike en temporale distorsie van spraakbewegings tydens die uitvoerstadium van die spraakproduksieproses (Darley, Aronson \& Brown, 1969a). Daar is egter aanduidings in die literatuur dat die serebellum ook betrokke is by hoëvlak motoriese programmering van liggaamsbeweging deur middel van 'n oop serebro-serebellêre kringbaansisteem (Allen \& Tsukahara, 1974; Brooks, 1986). Vanuit so 'n teorie kan daar geredeneer word dat alhoewel die serebellum en die motoriese korteks nie dieselfde funksies in die motoriese beheer van spraak vervul nie, aantasting van albei areas moontlik kan lei tot probleme met die voorbereiding van 'n "motoriese program" vir spraakproduksie (Kent \& Rosenbek, 1982).

Tradisioneel word die spraakproduksieproses beskryf as bestaande uit hoofsaaklik drie vlakke, nl. linguistiese enkodering, artikulatoriese programmering en laastens die uitvoer van bewegings (Itoh \& Sasanuma, 1984). In die lig van die neurofisiologiese onderskeid wat gemaak word tussen motoriese beplanning en programmering, verskaf hierdie tradisionele model nie genoegsame verklarings en interpretasiemoontlikhede vir navorsing aangaande neuromotoriese spraakafwykings nie. Van der Merwe (1994) postuleer dat daar vier hoofvlakke van spraakproduksie bestaan, nl. linguisties-simboliese beplanning, motoriese beplanning, motoriese programmering en uitvoer van beweging. Van der Merwe (1994) maak dus, in teenstelling met die huidige tendens in literatuur van neuromotoriese spraakafwykings om "beplanning" en "programmering" as dieselfde begrip te hanteer, 'n duidelike onderskeid tussen hierdie terme. Sy postuleer verder dat dit wel moontlik is dat die serebellum sekere progammeringsfunksies vervul in spraak soos die programmering van ruimtelik-temporale bewegingspesifikasies (byvoorbeeld spoed en tonus) voordat wérklike bewegings plaasvind, maar dat hierdie programmeringsfunksies verskil van die beplanningsfunksies van die assosiasie-areas tydens spraakproduksie. Brooks (1986) se uiteensetting ván die motoriese hierargie bevestig so 'n teorie. Op grond van die model van Van der Merwe (1994) is dit dus moontlik dat spraakklankdistorsie by serebellêre disartrie diej resultaat kan wees van die aantasting van beide die uitvoer- en programmeringsvlakke van die spraakproduksieproses.

Alhoewel daar nog nie uitsluitsel bestaan oor die funksies van kortikale en subkortikale motoriese dele geassosieer met verbale apraksie nie, postuleer Van der Merwe (1994) dat kortikale dele soos die area van Broca, die kortikaal-motoriese assosiasie-areas en ook die posteriorpariëtale areas betrokke is by die motoriese beplanning van spraakproduksie. Verbale apraksie reflekteer dan moontlik probleme met die beplanningsfase van spraakproduksie (Van der Merwe, 1994). In die geval van subkortikale skade, van veral sekere dele van die basale ganglia wat ook tot apraktiese simptome lei (Kertesz, 1984), is dit egter moontlik dat daar ook afwykings in die programmering van spraakbewegings is. Volgens die model van Van der Merwe (1994) kan spraakklankdistorsies by verbale apraksie dus die resultaat wees van probleme met die beplanning van ruimtelik-temporale spesifikasies van struktuurbewegings binne die grense van ekwivalensie asook met die programmering van bewegings.

Op grond van die model van Van der Merwe (1994) bestaan daar dus teoreties ' $n$ moontlikheid dat sekere ruimtelike en temporale aspekte van die kernsimptoom spraakklankdistorsie soos wat dit voorkom by serebellêre disartrie en verbale apraksie, moontlik kan oorvleuel op die vlak van motoriese programmering. 'n Tekort aan uitgebreide, objektiewe, vergelykende navorsing van die spraakkenmerke van persone met serebellêre disartrie en verbale apraksie, beperk egter die begrip van afwykende spraakproduksieprosesse betrokke by hierdie twee neuromotoriese spraakafwykings. 'n Uitgebreide akoestiese ondersoek na beide die ruimtelike en temporale aspekte van spraakklankdistorsie by serebellêre disartrie en verbale apraksie, binne 'n omvattende teoretiese model, kan dus meer lig werp op die aard van hierdie neuromotoriese spraakafwykings.

\section{METODE}

\section{Doelstellings}

Die doel van die studie is die akoestiese ontleding van sekere spraakparameters in die spraak van persone met serebellêre disartrie en verbale apraksie om so vergelykende data in te samel aangaande die voorkoms en aard van akoesties identifiseerbare spraakklankdistorsie by die onderskeie groepe. Om die akoestiese identifikasie van die aard van spraakklankdistorsie moontlik te maak, word die volgende betroubare en akoesties identifiseerbare spraakparameters van normale sprekers, sprekers met serebellêre disartrie en sprekers met verbale apraksie telkens ondersoek en vergelyk:

- Die spraakparameter stemaanvangstyd (SAT) soos gemeet tydens die produksie van 'n stemhebbende eksplosiewe klank, aangesien stemaanvangstyd 'n aanduiding verskaf van die sinchronisasie van glottale sluiting en supraglottale artikulasie (Tyler \& Waterson, 1991).

Die spraakparameter afsluitingsduur soos gemeet tydens die produksie van'n stemhebbende eksplosiewe klank, aangesien afsluitingsduur temporale aspekte van spraakproduksie, soos die spoed van artikulatoriese beweging en ruimtelike aspekte soos die omvang en akkuraatheid van artikulasiebewegings reflekteer.

Die spraakparameter konsonantduur soos gemeet tydens die produksie van 'n frikatiewe klank en 'n kontinuante klank, aangesien konsonantduur temporale aspekte van spraakproduksie soos die spoed van artikulatoriese bewegings reflekteer.

- Die spraakparameters formantfrekwensiewaardes van die eerste, tweede en derde formante van 'n kontinuante klank, aangesien formantwaardes ruimtelike aspekte van spraakproduksie soos die omvang en akkuraatheid van artikulatoriese bewegings reflekteer.

- Die spraakparameter aard van die energiespektrum soos gemeet tydens die produksie van 'n frikatiewe klank, aangesien frekwensie-omvang en plek van gekonsentreerde energie ruimtelike aspekte van spraak- 
produksie soos die omvang en akkuraatheid van artikulasiebewegings reflekteer.

\section{Proefpersone}

\section{Kriteria vir die seleksie van proefpersone en kontrolepersone}

Die volgende algemene kriteria is gestel:

- Die persone se taalbegrip, ouditiewe begripsvermoëns en visuele vermoëns moet van so'n aard wees dat die persoon die instruksies verstaan en die materiaal kan lees.

- Die proefpersone moet nie 'n binourale gehoorverlies van groter as $12 \%$ hê nie aangesien 'n groot gehoorverlies 'n invloed op spraak kan hê.

\section{Proefpersone met serebellêre disartrie:}

- Die proefpersone moet deur'n neuroloog gediagnoseer wees as breinbeseerd met serebellêre skade. Die neuromotoriese aantasting moet so suiwer as moontlik tot die serebellum beperk wees.

- Die proefpersone moet disartriese spraak vertoon.

- Die sprekers moet gepaardgaande kenmerkende liggaamlike neuromotoriese simptome toon ter bevestiging van serebellêre skade bv. ataksie, dismetrie, disdiadokokinese, intensietremor en hipotonie.

Proefpersone met verbale apraksie:

- Die proefpersone moet deur 'n neuroloog gediagnoseer wees as breinbeseerd met ' $n$ fokale letsel wat nie 'n serebellêre lokalisasie het nie.

- Die proefpersone moet verkieslik 'n suiwer verworwe verbale apraksie vertoon en indien 'n gepaardgaande afasie voorkom mag dit slegs minimaal wees.

- Die proefpersone moet voldoen aan kriteria soos gestel deur Kent en Rosenbek (1983) nl

* onvlot spraakproduksie met probeer-en-tref artikulasiebewegings.

* onkonstante foutproduksie by herhaalde produksie van dieselfde woord

* disprosodie.

* probleme met inisiëring van uitinge.

- Die graad van apraksie moet die herhaling van uitinge moontlik maak. Geen gepaardgaande disartriesimptome mag voorkom nie.

\section{Kontrolepersone:}

- Die kontrolepersone moet normaalsprekende volwassenes wees wat geen spraakafwykings of geskiedenis van spraak- of neurologiese afwykings het nie.

- Die kontrolepersone moet : van dieselfde geslag as die proefpersone wees; binne die ouderdomsgrens van die proefpersone val; moet dieselfde spreektaal as die proefpersone hê.

\section{Geselekteerde proefpersone en kontrolepersone}

Proefpersone met serebellêre disartrie:

- Twee sprekers met verworwe serebellêre disartrie wat voldoen aan die vasgestelde vereistes is gevind.
- Proefpersoon 1 (Pp 1) is 'n manlike spreker wat na 'n motorongeluk in 1979 algemene geringe breinskade en ernstige serebellêre skade opgedoen het. Hy toon tans neuromotoriese liggaamlike simptome soos ataksie, dismetrie, hipotonie, disdiadokokinese en intensietremor.

- Proefpersoon 2 ( $\mathrm{Pp} \mathrm{2}$ ) is 'n manlike spreker wat ongeveer in 1989 ligte tekens begin toon het van balansprobleme. Die oorsaak van die aantasting is in Maart 1992 gediagnoseer as serebellêre degenerasie weens veelvuldige sklerosè. Veelvuldige sklerose neem meestal oorsprong in die serebellum (Bannister, 1973). Alhoewel veelvuldige sklerose geleidelik 'n gemengde neurologiese toestand tot gevolg kan hê, toon $\mathrm{Pp} 2$ slegs kenmerkende liggaamlike neurologiese simptome van 'n serebellêre aard.

- Proefpersoon 2 se algemene graad van aantasting blyk groter te wees as die van $\mathrm{Pp} 1$, aangesien $\mathrm{Pp} 2$ 'n erger graad van liggaamlike simptome vertoon as $\mathrm{Pp} 2$ en ook meer disartries voorkom.

Proefpersoon met verbale apraksie:

- Een persoon met verworwe verbale apraksie wat voldoen aan die vasgestelde vereistes is gevind. Die spreker met verbale apraksie is 'n manlike spreker, proefpersoon $3(\mathrm{Pp} 3)$, wat'n gepaardgaande minimale Broca Afasie vertoon $(A Q=64)$ volgens die Western Aphasia Battery (Kertesz, 1982).

- Proefpersoon 3 het verworwe breinskade opgedoen as die resultaat van twee serebro-vaskulêre insidente onderskeidelik in 1984 en 1989 . Infarksies het voorgekom in die anterior been van die linker interne kapsula en in die regter oksipitale gebied. Die spreker toon ' $n$ regsydige hemiplegie maar daar is geen aanduiding van' $n$ waarneembare boonste motorneuron gesig- of tongparese nie.

- Proefpersoon 3 toon verbale apraksie in 'n erge graad maar is in staat tot nabootsing van woorde. Tydens spraak kom duidelike soekbewegings en worstelgedrag voor, asook pogings tot selfkorreksie, onkonstante distorsies en vervangings, en onkonstante produksies met die herhaling van uitinge.

\section{Materiaal}

Die materiaal is so gekies dat dit die omvattende ruimtelike en temporale ondersoek van spraakklankdistorsie in 'n verskeidenheid van kontekste moontlik maak, om sodoende 'n meer verteenwoordigende beeld te verkry van spraakproduksie by die onderskeie diagnostiese groepe.

Die materiaal is saamgestel deur die kontinuante klank [1], die stemhebbende eksplosiewe klank [d] en die frikatiewe klank [s] te varieer in die inisiële en mediale klankposisies van onsineenhede en woorde, binne sinsverband met 'n KVKV- en KVKVK-struktuur onderskeidelik. Die klanke is gekies omdat dit verskillende wyses van artikulasie verteenwoordig en akoesties maklik identifiseerbaar is. Die vokaál [a:] is telkens met die klanke in die onsineenhede gekombineer en is soos die. ander klanke in die woorde en sinne lukraak gekies. Twee verskillende klankstrukture is gekies om so spraak- 
klankdistorsie in materiaal van verskillende uitinglengte te ondersoek.

Die materiaal bestaan uit 12 onsineenhede en 10 woorde binne sinsverband. Die onsineenhede is telkens 5 keer herhaal en die sinne drie keer. In totaal het elke persoon dus 90 uitinge geproduseer. Tabel 1 gee 'n volledige uiteensetting van die wyse van die samestelling van die teikenmateriaal en die gemete spraakparameters binne elke uiting.

Tabel 1. Samestelling van die teikenmateriaal en die gemete spraakparameters binne elke uiting

1.1

\begin{tabular}{|c|c|c|c|c|}
\hline Klank & & \multicolumn{3}{|c|}{ [d] } \\
\hline Konteks & $\begin{array}{l}\text { Klank- } \\
\text { kombi- } \\
\text { nasie }\end{array}$ & $\begin{array}{l}\text { Klank- } \\
\text { posisie }\end{array}$ & $\begin{array}{l}\text { Para- } \\
\text { meters }\end{array}$ & $\begin{array}{l}\text { Mate- } \\
\text { riaal }\end{array}$ \\
\hline \multirow{4}{*}{$\begin{array}{l}\text { Onsin- } \\
\text { woorde }\end{array}$} & \multirow{2}{*}{ KVKV } & inisieël & SAT & data \\
\hline & & mediaal & $\mathrm{AD}$ & sada \\
\hline & \multirow{2}{*}{ KVKVK } & inisieël & SAT & dadaf \\
\hline & & mediaal & $\mathrm{AD}$ & sadaf \\
\hline \multirow{2}{*}{ Sinne } & \multirow{2}{*}{ KVKVK } & inisieël & SAT & dames \\
\hline & & mediaal & $\mathrm{AD}$ & dadel \\
\hline
\end{tabular}

1.2

\begin{tabular}{|c|c|c|c|c|c|c|}
\hline Klank & \multicolumn{6}{|c|}{ [s] } \\
\hline Konteks & $\begin{array}{l}\text { Klank- } \\
\text { kombi- }\end{array}$ & $\begin{array}{l}\text { Klank- } \\
\text { posisie }\end{array}$ & \multicolumn{3}{|c|}{ Parameters } & $\begin{array}{l}\text { Mate- } \\
\text { riaal }\end{array}$ \\
\hline \multirow{4}{*}{$\begin{array}{l}\text { Onsin- } \\
\text { woorde }\end{array}$} & \multirow{2}{*}{ KVKV } & inisieẹ́l & $\mathrm{KD}$ & FO & Piek & sasa \\
\hline & & mediaal & $\mathrm{KD}$ & FO & Piek & dasa \\
\hline & \multirow{2}{*}{ KVKVK } & inisieềl & $\mathrm{KD}$ & FO & Piek & sasaf \\
\hline & & mediaal & $\mathrm{KD}$ & FO & Piek & dasaf \\
\hline \multirow{2}{*}{ Sinne } & \multirow{2}{*}{ KVKVK } & inisieèl & $\mathrm{KD}$ & FO & Piek & sabel \\
\hline & & - & - & - & - & - \\
\hline
\end{tabular}

1.3

\begin{tabular}{|l|l|l|l|l|l|}
\hline Klank & \multicolumn{5}{|c|}{ [I] } \\
\hline Konteks & $\begin{array}{l}\text { Klank- } \\
\text { kombi- } \\
\text { nasie }\end{array}$ & $\begin{array}{l}\text { Klank- } \\
\text { posisie }\end{array}$ & \multicolumn{2}{|c|}{ Parameters } & $\begin{array}{l}\text { Mate- } \\
\text { riaal }\end{array}$ \\
\hline \multirow{2}{*}{$\begin{array}{l}\text { Onsin- } \\
\text { woorde }\end{array}$} & \multirow{2}{*}{ KVKV } & insieël & KD & F1-F3 & lala \\
\cline { 2 - 6 } & \multirow{2}{*}{ KVKVK } & mediaal & KD & F1-F3 & dala \\
\hline \multirow{2}{*}{ Sinne } & \multirow{2}{*}{ KVKVK } & mediaal & KD & F1-F3 & lalaf \\
\cline { 3 - 7 } & & - & - & F1-F3 & dalaf \\
\hline
\end{tabular}

\section{Apparaat}

\section{Opname-apparaat}

- 'n Nakamichi 550 "Versatile stereo casette system".

- 'n Bever Dynamic M 201 N(C) mikrofoon.

- BASF Chrome Maxima 60 minute magneetbandkasette.

\section{Analise-apparaat}

- 'n Nakamitchi 550 kassetspeler is gebruik om die spraaksein soos opgeneem op BASF Chrome Maxima magneetbandkassette na die Kay DSP Sonagraph te stuur.

- Die spraaksein kan met behulp van die JBL Pro III luidsprekers gemonitor word.

- Die spraaksein word geanaliseer deur 'n digitale seinprosesseerder van Kay Elemetrics Corp. nl. Sonagraph Model 5500 en vertoon op 'n NEC Multisync II vertoonskerm. Drie verskillende toepaslike opstellings is vir die onderskeie analises gebruik.

- 'n Weergawe van die beeld wat op die skerm verskyn kan met behulp van 'n termiese drukker, Kay DSP drukker model 5510 verkry word.

\section{Prosedure vir spraakseinopname}

- Die spraakopnames is in die klankdigte opnamelokaal van die Taallaboratorium van die Universiteit van Pretoria gedoen.

- Die mikrofoon is op ' $n$ afstand van $10 \mathrm{~cm}$ voor die persoon se mond geposisioneer om ekspirasiegeraas op die opname tot die minimum te beperk.

- Die materiaal is vooraf aan die persone gegee om deur te lees sodat hulle bekend kon raak daarmee. Die volgorde van die materiaal is konstant gehou vir al die sprekers.

- Die proefpersone is gevra om elke woord vyf keer direk na mekaar te herhaal en elke sin drie keer.

- Vir die verbaal-apraktiese spreker is die opname effens gewysig deurdat die proefpersoon die geleentheid gegee is om die uiting 'n paar keer te oefen (Kent \& Rosenbek, 1983). Daar is deurentyd 'n opname gemaak totdat vyf produksies van elke uiting verkry is.

\section{Analise van data}

\section{Analise van die spraakparameter stemaanvangs- tyd (SAT)}

- Vir die meting van SAT is 'n analise-opstelling met 'n gekombineerde vertoning bestaande uit 'n golfvorm met'n amplitudeverloop en 'n grondtoonverloop sowel as 'n spektrogram gebruik. By die bepaling van SATwaardes is die twee vertonings voortdurend vergelyk om sodoende die betroubaarheid van metings te verhoog.

- 'n Positiewe stemaanvangstyd word gedefinieer as die tyd wat verloop vanaf die aanvang van die vrylating van ploffing tot by die aanvang van die eerste 
vertikale striasie op die spektrogram wat glottale pulsering verteenwoordig (Lisker en Abramson, 1964). SAT-waardes lê op 'n kontinuum en kan positiewe en negatiewe waardes aanneem. In die geval van 'n negatiewe SAT-waarde gaan glottale pulserings die ploffing vooraf en word die meting gedoen vanaf die aanvang van glottale pulserings tot by die ploffingsgedeelte.

\section{Analise van die spraakparameter afsluitingsduur}

Afsluitingsduur is gedefinieer as die periode in millisekondes wat verloop vanaf die einde van die voorafgaande vokaal tot voor die aanvang van die ploffing van die eksplosief. Wanneer daar nie aanduidings van ' $n$ volledige afsluiting waarneembaar was op die golfvorm nie, is die spektrogram gebruik ter vergelyking om so betroubaarheid van metings te verhoog.

\section{Analise van die spraakparameter-konsonantduur}

Vir die meting van konsonantduur is analise-opstellings gekies wat gelyktydig 'n spektrogram, 'n gekombineerde golfvorm en 'n gemiddelde amplitudespektrum van 'n spesifieke gedeelte van 'n uiting vertoon. Die frekwensieomvang van die analise-opstellings het verskil $\mathrm{nl} .0-4 \mathrm{kHz}$ vir die [l] en $0-16 \mathrm{kHz}$ vir die [s]. Konsonantduur is gedefinieer as die periode in millisekondes (msek) wat'n konsonant spektrografies waarneembaar is.

\section{Analise van die eerste, tweede en derde formant-} frekwensiewaardes van die [l]

- Vir die meting van die formantfrekwensiewaardes is dieselfde frekwensie-omvang gekies as wat gebruik is vir die analise van konsonantduur van die [l] (nl. $0-4 \mathrm{kHz}$ ).

- Die tydkursors op die spektrogram is so geplaas dat dit 'n verteenwoordigende stabiele deel van die [1] afbaken en 'n gemiddelde amplitudespektrum daarvan verkry. Met behulp van frekwensiekursors is die formantfrekwensiewaarde vanaf die gemiddelde spektrum bepaal deur die tweede energiepiek as F1, die derde piek as F2 en die vierde piek as F3 te noteer. Die gemiddelde amplitude-spektrum en spektrogram is deurentyd vergelyk.

\section{Analise van die omvang van energie en plek van gekonsentreerde energie van die [s]}

- Vir die meting van die omvang van akoestiese energie en plek van gekonsentreerde energie van die [s] is dieselfde opstelling gebruik as by konsonantduur (d.w.s. 0-16 kHz).

- Met behulp van tydkursors is 'n verteenwoordigende deel van die [s] op die spektrogram afgebaken en frekwensiekursors geplaas op die onderste en boonste grense.

- Die plek van gekonsentreerde energie is bepaal deur die energiepiek met die hoogste waarde op die amplitudespektrum te identifiseer. Waar twee ewe sterk pieke waargeneem is, is die waarde van die tweede piek van energie genoteer.

\section{Verwerking van data}

\section{Verwerking van SAT-metings}

Vir die berekening van hierdie SAT-foutwaarde is SATwaardes van -180 millisekondes tot +15 millisekondes (msek) aanvaar as die normale perke (Zlatin, 1974). Die gemiddelde SAT-foutwaarde vir elke groep uitinge van elke persoon is bereken deur die hoeveelheid millisekondes bokant 15 of onder 180 oor die drie herhalings bymekaar te tel en deur drie te deel (Van der Merwe et al., 1989). Hierna is 'n gemiddelde SAT-foutwaarde vir elke persoon bereken. 'n Gemiddelde SAT-foutwaarde vir die onderskeie diagnostiese groepe is vervolgens bereken uit die gemiddelde foutwaardes van die betrokke proef- en konrolepersone.

\section{Verwerkings van afsluitingsduurmetings van die [d] en konsonantduurmetings van die [l] en [s]}

Die resultate van afsluitingsduurmetings van die [d] en konsonantduurmetings vir die [1] en die [s] is telkens op dieselfde wyse verwerk. Eerstens is 'n gemiddelde duurwaarde vir die eerste drie herhalings van elke onsineenheid en elke woord van elke persoon bereken. Uit die gemiddeldes van elke persoon is tweedens 'n gemiddelde duurwaarde vir elke onsineenheid en elke woord vir die betrokke diagnostiese groepe bereken. Uit die gemiddelde duurwaardes van die verskillende onsineenhede is derdens' $n$ totale gemiddelde duurwaarde vir onsineenhede bereken vir elke diagnostiese groep en vierdens op dieselfde wyse 'n totale gemiddelde duurwaarde vir woorde vir elke diagnostiese groep. Laastens is 'n gemiddelde duurwaarde bereken vir elke diagnostiese groep, uit die som van die onderskeie gemiddelde waardes vir onsineenhede en woorde tesame.

Verwerkings van die resultate van formantfrekwensiewaardes van die [l]

Die gemete formantfrekwensiewaardes van die eerste drie formante van die [1] is telkens op dieselfde wyse verwerk. Eerstens is daar vir elke persoon gemiddelde formantfrekwensiewaardes vir formante een, twee en drie bepaal uit die som van die onderskeie gemete formantfrekwensiewaardes vir onsineenhede, en woorde tesame. Tweedens is gemiddelde formantfrekwensiewaardes vir elke formant van elke diagnostiese groep bepaal uit die som van die betrokke gemiddelde formantfrekwensiewaardes van die persone. Derdens is formantratio's bepaal vir elke persoon en elke diagnostiese groep vir formant twee teenoor formant een (F2:F1) en vir formant drie teenoor formant een (F3:F1) volgens die metode van Dalston (in Baken en Daniloff, 1991).

\section{Verwerking van die resultate van omvang van akoestiese energie en die plek van gekonsentreerde energie van die [s]}

Vir die bepaling van die omvang van akoestiese energie is die gemiddelde minimum en maksimum frekwensiewaardes van elke persoon en elke diagnostiese groep bereken. Die gemiddelde minimum en maksimum frekwensiewaardes van elke persoon is bereken uit die 
som van die gemete onderskeie minimum en maksimum frekwensiewaardes van onsineenhede en woorde tesame. Uit hierdie persoongemiddeldes is vervolgens gemiddelde minimum en maksimum frekwensiewaardes vir die onderskeie diagnostiese groepe bepaal. Persoon- en diagnostiese groepgemiddeldes is verder op dieselfde wyse bereken vir die plek van gekonsentreerde energie van die [s].

\section{RESULTATE EN BESPREKING}

\section{Resultate en bespreking van stemaanvangstyd- metings}

Die resultate van hierdie spraakparameter dui op verskille in die aard van die waargenome spraakklankdistorsie by die onderskeie afwykings. Figuur 1 illustreer die gemiddelde SAT-foutwaardes van die verskillende diagnostiese groepe. Die verbaal-apraktiese spreker toon die grootste foutwaarde (nl.14.8) van die verskillende groepe.

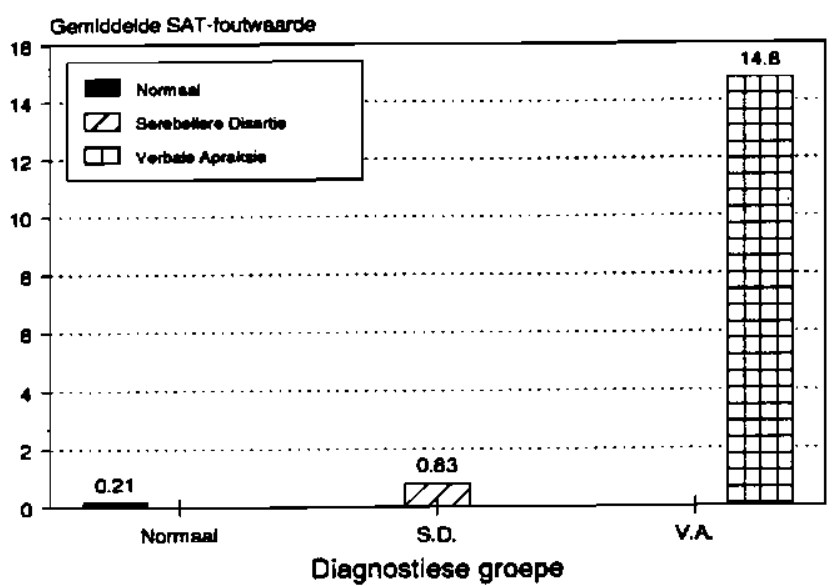

Figuur 1. Gemiddelde SAT-foutwaardes van die onderskeie diagnostiese groepe.

Ontleding van die SAT-data toon dat die serebellêre disartriesprekers se SAT-resultate konstant afwykend negatiewe SAT-waardes toon by Pp 2 terwyl Pp 1 se waardes rondom die normale perke sentreer. Teoreties beskou impliseer' $n$ negatiewe SAT-waarde dat fonasie 'n aanvang neem voordat die lugvrylating vir afsluitingsklankproduksie plaasvind (Lisker \& Abramson, 1964). Produksie van die [d] vereis hoofsaaklik integrasie van produksiekomponente soos stemgewing, velêre en alveolêre sluiting om die opbou van lugdruk moontlik te maak en verder verbreking van die alveolêre afsluiting met gevolglike ploffingsproduksie. By nadere ondersoek blyk dit egter dat die gemete negatiewe SAT-waardes en waarneembare stemvoorloop by $\mathrm{Pp} 2$ die resultaat is van 'n perseptueel hoorbare nasalering van die aanvangsklank asook swak afsluitings- en ploffingsproduksie wat meting bemoeilik het (sien resultate aangaande afsluitingsduurmetings vir verdere toeligting). Stemgewing by $\mathrm{Pp} 2$ is dus wel akkuraat in tyd, maar blyk skynbaar afwykend negatief te wees weens genasaleerde aanvangsdistorsie van die [d], omdat duidelike afsluitingsproduksie nie plaasgevind het nie. Dit blyk dus asof die aanvang van die ploffingsgedeelte vertraag is, moontlik weens swak velêre sluiting as gevolg van hipotonie of onwillekeurige bewegings. Daar is dus sprake van swak interartikulator- sinchronisasie weens stadige velêre sluiting en nie weens stadige inisiëring van stemgewing nie. Die resultate dui dus moontlik op intakte beplanning van die artikulatoriese bewegings maar op probleme met die uitvoer van die beplande bewegings.

Die feit dat $\mathrm{Pp} 1$ nie soortgelyke afwykende SATresultate vertoon as $\mathrm{Pp} 2$ nie, is moontlik 'n aanduiding dat die SAT-afwykings by die serebellêre disartriesprekers direk verband hou met die erns van die aantasting. Kent et al. (1979) vind ooreenstemmende resultate deurdat SATwaardes van klanke soos die [t], [p] en [k]-klanke verleng word namate die graad van aantasting toeneem.

Die verbaal-apraktiese spreker in die huidige studie toon in teenstelling met die serebellêre disartriesprekers 'n hoë SAT-foutwaarde en ook slegs SAT-waardes van 'n positiewe aard. Die positiewe SAT-waarde dui daarop dat glottale pulserings (d.w.s. fonasie)'n aanvang neem nadat die ploffing van die afsluiting vir die [d] geproduseer is. Die vertraging in stemgewing by $\mathrm{Pp} 3$ reflekteer moontlik probleme met die temporale interartikulator-sinchronisasie van tongbeweging en glottale sluiting wat 'n spektrografies waarneembare distorsie van die [d] as byna 'n [t] tot gevolg het. Aangesien die SAT-waardes van die spreker in hierdie studie nooit die gegewe positiewe SATwaarde van +40 msek (Zlatin, 1974) vir stemlose klanke bereik het nie ('n gemiddelde SAT-waarde van $26.6 \mathrm{msek}$ kom voor), kan die afleiding gemaak word dat die spreker nie die [d] fonologies vervang het met ' $n$ [t] nie en dat ' $n$ spraakklankdistorsie eerder teenwoordig is. Soortgelyke afleidings is deur Van der Merwe et al. (1989) gemaak

Die SAT-resultate van die verbaal-apraktiese spreker in die huidige studie stem ooreen met bevindinge van Freeman, Sands en Harris (1978) naamlik dat sprekers met verbale apraksie geen stemvoorlope vir stemhebbende afsluitingsklanke het nie. Navorsing toon oor die algemeen dat stemhebbende klanke meer stemloos gemaak word deur verbaal-apraktiese sprekers as omgekeerd (Wertz, LaPointe en Rosenbek, 1984). Kent en Rosenbek (1983) vind in teenstelling met huidige bevindinge SAT-foute van 'n groot negatiewe aard by sommige van hul proefpersone en wys daarop dat probleme met koördinasie en tydsberekening akoesties verskillend manifesteer by verskillende verbaal-aprak tiese sprekers. Daar kan gespekuleer word dat verbaal-apraktiese sprekers moontlik ideosinkratiese aantasting van sinchronisasie van fonasie en artikulasie vertoon en dat SAT-foute, al hoewel dit voorkom by verbaal-apraktiese sprekers, onvoorspelbaar is in terme van die aard van die SAT-foute (Freeman et al., 1978; Van der Merwe et al., 1989). Daar moet egter in gedagte gehou word dat slegs data van een verbaal-apraktiese spreker in die huidige studie beskikbaar is, wat dus spekulasies hieromtrent aansienlik beperk.

\section{Resultate van afsluitingsduurmetings}

Figuur 2 toon dat die serebellêre disartriesprekers se gemiddelde afsluitingsduurwaarde (nl. 0.09 sek) gering korter is as die van die normale sprekers (nl, 0.1 sek) terwyl die verbaal-apraktiese spreker die langste afsluitingsduurwaarde vertoon (nl. 0.49 sek).

Dis insiggewend dat die produksie van 'n swak alveolêre afsluiting vir die [d], waarneembaar is by beide serebellêre disartriesprekers. Spektrografiese ontleding toon dat feitlik geen onderbreking in glottale pulserings met 
Afoluttingsduur (sek.)

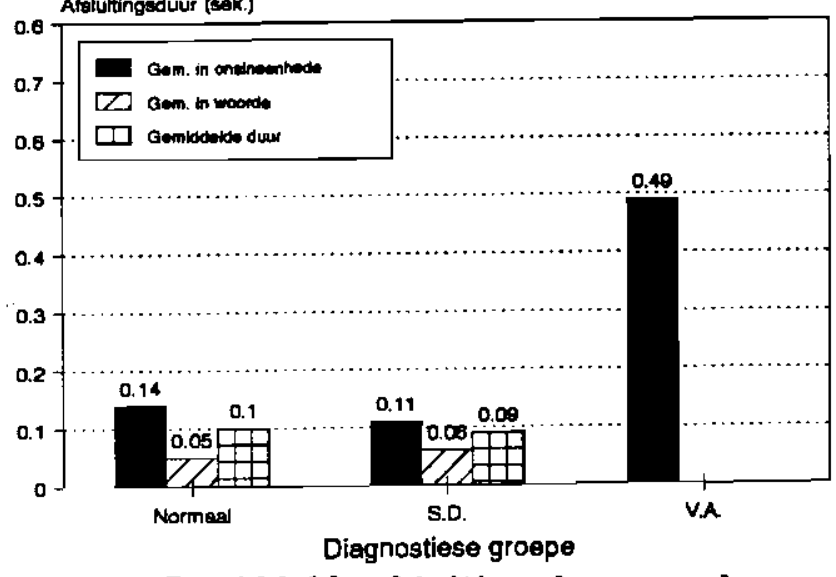

Figuur 2. Gemiddelde afsluitingsduurwaardes van die [d] van die onderskeie diagnostiese groepe, soos bereken vir onsineenhede, woorde en vir woorde en onsineenhede tesame.

aanduidings van 'n ploffing waarneembaar is op die golfvorm nie, terwyl die spektrogram ook 'n mate van aaneenlopendheid in die formante vertoon. Die aaneenlopende teenwoordigheid van glottale pulserings en energie op die spektrogram bemoeilik dus die bepaling van die afsluitingsgedeelte van die [d] in die woord en het tot gevolg dat verkorte tot normale afsluitingsduur gemeet word by die serebellêre disartriesprekers. Hierdie tendens dra dus by tot die gemete negatiewe SAT-waardes by veral Pp 2. Proefpersoon 2 se SAT-waardes was gevolglik in twee van die totaal van nege uitinge nie meetbaar nie, weens die feit dat 'n duidelike ploffing vir die [d] nie teenwoordig was nie. Die resultate en afleidings van die huidige studie aangaande swak afsluitingsklankproduksie by die serebellêre disartriesprekers word ondersteun deur die resultate van vorige studies. Kent en Netsell (1975) vind konstante afsluitingsklankdistorsie van die [t]-, [d]- en [g]-klanke deur serebellêre disartriesprekers deurdat die afsluitingsgedeelte van die klank of weggelaat word, (waarskynlik waarneembaar as 'n vokaalagtige distorsie), of met 'n frikatiewe kwaliteit geproduseer word. Hulle rapporteer ook ' $n$ afwesigheid van 'n prominente ploffing van die [g]-klank en skryf dit toe aan 'n onvermoë van die tong om kontak te maak met die alveolêre rif weens onvoldoende spierkrag of onwillekeurige bewegings. Hierdie resultate dui moontlik op probleme op 'n uitvoervlak van spraakproduksie. Dis egter ook moontlik dat die voorafgaande resultate uitvalle op 'n programmeringsvlak van spraakproduksie kan reflekteer, waartydens daar sprake is van "spier-spesifieke" programmering van omvang en rigting van spraakbewegings (Van der Merwe, 1994).

In teenstelling met die serebellêre disartriespreker in die studie ( $\mathrm{Pp} 2)$ toon die verbaal-apraktiese spreker $(\mathrm{Pp}$ 3) spektrografies beskou 'n duidelike afsluitings- of ploffingsgedeelte maar stemgewing en ploffing word "afsonderlik" geproduseer. Fonasie neem dus 'n aanvang nadat die afsluiting opgehef is. Hierdie resultate dui daarop dat daar nie probleme voorkom met die kwaliteit van afsluitingsproduksie by die verbaal-apraktiese spreker nie. Verlengde afsluitingsduurwaardes by verbaalapraktiese sprekers word ook deur ander navorsers gerapporteer (Kent \& Rosenbek, 1983; Hardcastle et al., 1985). Verlenging van afsluitingsduur by die verbaalapraktiese spreker kan moontlik verklaar word as 'n kompensatoriese reaksie om sodoende meer tyd toe te laat vir die motoriese beplanning van die daaropvolgende bewegingskomponente van die uiting (Kent \& Rosenbek, $1982 ; 1983)$. Hierdie verklaring word moontlik ondersteun deur die waarneming in die huidige studie dat die verbaalapraktiese spreker langer afsluitingsduurwaardes vir KVKVK-eenhede as vir KVKV-eenhede vertoon. Navorsing aangaande die invloed van verskillende kontekste op die spraak van verbaal-apraktiese sprekers dui daarop dat die KVKVK-eenheid vir'n verbaal-apraktiese spreker moeiliker is om te beplan as die KVKV-eenheid (Van der Merwe et al., 1988; 1989). Langer afsluitingsduurwaardes sou dan moontlik meer tyd toelaat vir die spreker om die uiting te beplan.

\section{Resultate en bespreking van konsonantduur-} metings van die [1] en die [s]

Figure 3 en 4 illustreer die resultate van konsonantduurmetings. Die serebellêre disartriesprekers en die verbaal-apraktiese spreker toon volgens die resultate ongeveer dieselfde mate van temporale distorsie by die [1]-klank, deurdat die mate van verlengde kontinuantduur min of meer gelyk is (sien Figuur 3). Vir die [s]-klank toon die verbaal-apraktiese spreker egter 'n groter mate van temporale distorsie as die serebellêre disartriesprekers.

Die serebellêre disartriesprekers toon volgens die

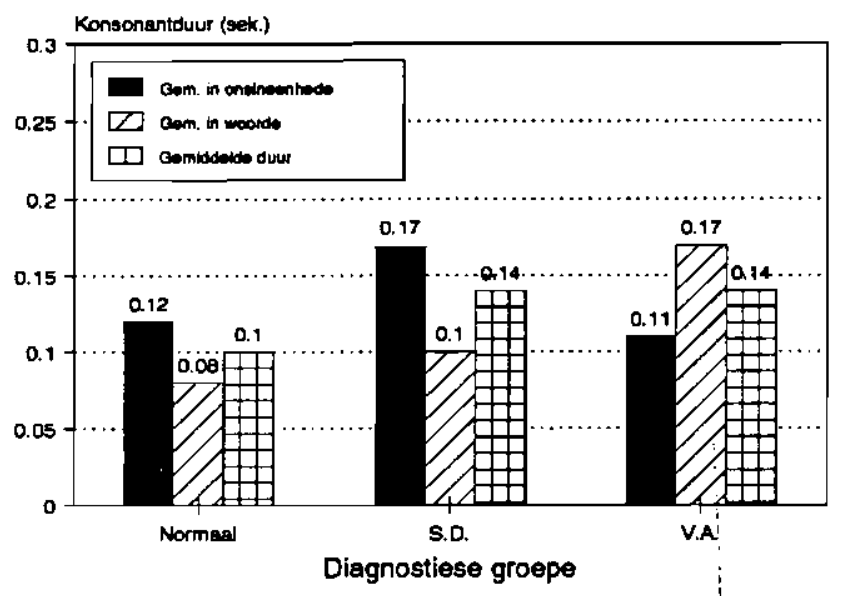

Figuur 3. Gemiddelde konsonantduurwaardes van die [1] van die onderskeie diagnostiese groepe.

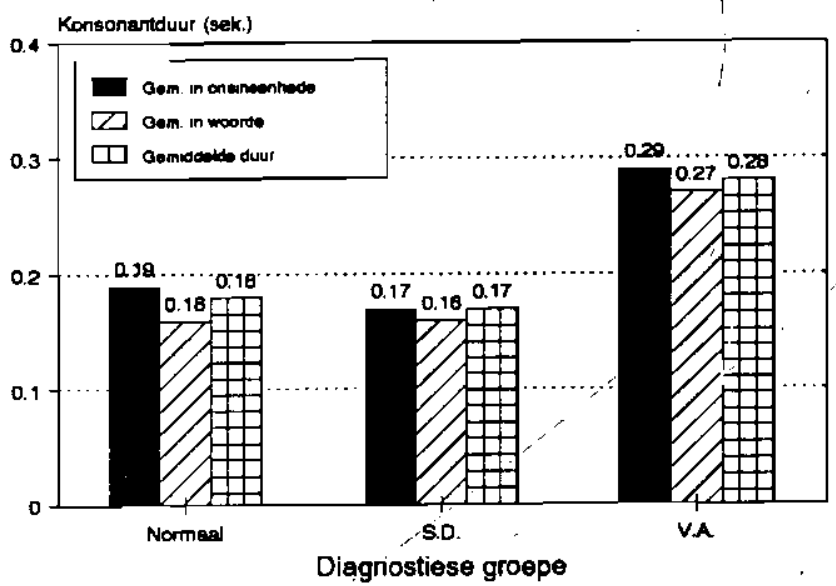

Figuur 4. Gemiddelde frikatiewe duurwaardes vir die [s] van die onderskeie diagnostiese groepe. 
resultate verlengde konsonantduur vir beide die [1] en die [s]-klanke. Verlengde segmentele duur by sprekers met serebellêre disartrie is ook deur ander navorsers bevind (Kent \& Netsell, 1975; Kent et al., 1979; Kent \& Rosenbek, 1982). Die huidige resultate stem ooreen met die van Kent et al., (1979) wat verlengde konsonantduur ooreenkomstig die graad van aantasting vind by serebellêre disartriesprekers. Temporale distorsie in die vorm van verlengde konsonantduur by die serebellêre disartriesprekers kan eerstens verklaar word as die direkte gevolg van neuromotoriese simptome soos hipotonie, ataksie en onwillekeurige bewegings wat' $n$ afname in die spoed van bewegings kan veroorsaak (Grunwell \& Huskins, 1979) en dus moontlik probleme op 'n uitvoervlak van spraakproduksie reflekteer. Tweedens kan verlengde duur beskou word as die resultaat van kompensasie vir die onderliggende simptome, om sodoende meer tyd toe te laat vir die evaluasie van terugvoer aangaande die posisies en bewegings van die artikulators (Kent \& Rosenbek, 1982). Kent et al., (1979) noem in aansluiting by so'n beskouing dat wanneer sprekers met serebellêre disartrie genoeg tyd tot hulle beskikking het, hulle toepaslike artikulatoriese posisies kan bereik.

In die huidige studie vertoon $\mathrm{Pp} 1$ duurwaardes langer as die normale vir die [l] maar by die frikatiewe [s]-klank kom distorsie voor in die vorm van duurwaardes korter as die normale. Kent et al., (1979) rapporteer ook duurwaardes kleiner as die normale vir die [s]-klank vir persone met minder ernstige serebellêre disartrie maar verskaf geen ander verklaring daarvoor as die graad van aantasting nie. Daar kan gespekuleer word dat Pp 1 moontlik as gevolg van 'n unieke kompensasiewyse spraak vinniger as die normale produseer of dat vinniger as normale [s]-produksie 'n unieke spraakkenmerk van die persoon was voordat die verworwe spraakafwyking ingetree het. Formele metings van spraakspowd en uitinglengte is egter nie beskikbaar ter verdere uitbreiding van die spekulasies rondom spraakspoed nie. Metings van die akoestiese omvang van energie van die [s] het egter meer lig gewerp op die artikulasie-eienskappe van die [s] (sień verdere bespreking).

Die verbaal-apraktiese spreker toon ook soos die serebellêre disartriesprekers temporale distorsie van die [s] maar verskille in die aard en graad daarvan is opgemerk. 'n Groter maté van temporale spraakklankdistorsie kom voor by die [s] van die verbaalapraktiese spreker deurdat duurwaardes groter is as die waardes van die serebellêre disartriesprekers en die normale waardes (sien Figuur 4). Hierdie resultaat stem ooreen met algemene bevindinge dat verbaal-apraktiese sprekers verlengings van woordsegmente toon (Kent \& Rosenbek, 1983; Kent \& McNeil, 1987; Van der Merwe et al., 1989). Navorsers soos Kent en McNeil (1987) voer aan dat verlengde segmentele en intersegmentele duur by verbaal-apraktiese sprekers die direkte resultaat kan wees van foutiewe fonetiesmotoriese kodering van die uiting. Ander outeurs beskou weer verlengde segmentele duur teoreties as 'n kompensatoriese metode (Kent \& Rosenbek, 1982; Van der Merwe et al., 1989).

'n Interessante spektrografiese waarneming by duurmetings van die verbaal-apraktiese spreker is die konstante voorkoms van intersillabe-pouserings, selfs waar normale duurwaardes bereik is. In teenstelling hiermee het intersillabe-pouserings nooit by die serebellêre disartriesprekers voorgekom nie en is aaneenlopende produksies sonder duidelike afsluitings eerder opgemerk. Kent en McNeil (1987) vind in ooreenstemming met hierdie resultate intersegmentduur langer as die normale by verbaal-apraktiese sprekers. Hierdie bevindinge vind dus tot ' $n$ mate aansluiting by die teorie dat intersillabepouserings as 'n kompensatoriese metode gebruik word.

'n Verdere interessante waarneming wat by die duurmetings van die [s] sowel as die [1]-klank van die verbaal-apraktiese spreker waarneembaar is en nie by die sprekers met serebellêre disartrie voorkom nie, is dat die verbaal-apraktiese spreker gering groter duurwaardes vir KVKVK-eenhede vertoon as vir KVKV-eenhede. Van der Merwe et al., (1989) vind ooreenstemmende groter duurwaardes vir KVKVK-eenhede as vir KVKV-eenhede by verbaal-apraktiese sprekers. Kontekste wat moontlik hoër eise aan die spreker stel in terme van motoriese beplanning het dus moontlik verlengde duur tot gevolg (Van der Merwe et al., 1989). Die afleiding kan dus gemaak word dat die verbaal-apraktiese spreker in die huidige studie ook moontlik probleme vertoon met die beplanning van spraak.

\section{Resultate en bespreking van die meting van die} omvang van akoestiese energie van die [s]-klank

Figuur 5 illustreer die bevindinge van die meting van die omvang van akoestiese energie van die [s]-klank.

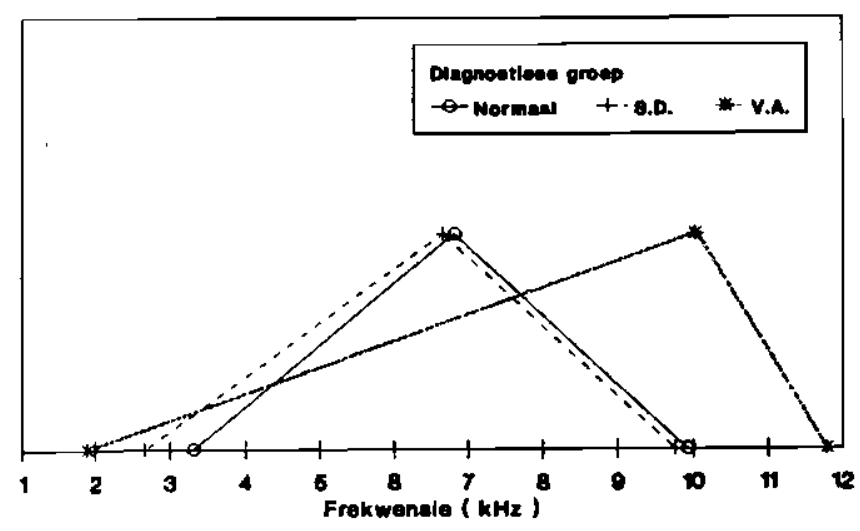

Figuur 5. Gemiddelde minimum en maksimum frekwensie-waardes en plek van gekonsentreerde energie vir die [s] van die verskillende diagnostiese groepe.

Die moontlikheid dat unieke [s]-produksie by Pp1 voorkom, word verder ondersteun deur resultate van die meting van die omvang van akoestiese energie by die [s] van $P$ p1. Die serebellêre disartriesprekers as groep vertoon ruimtelike distorsie van die [s] deurdat die omvang van die [s] skuif na 'n effens kleiner waarde met die minimum waarde meer afwykend as die maksimum waarde (sien Figuur 5).'n Verlaging in die minimum frekwensiewaardes van die [s] kan moontlik dui op'n verminderde konstriksie vir [s]-produksie. Proefpersoon 1 toon 'n gering groter omvang van akoestiese energie as $\mathrm{Pp} 2$ wat daarop kan dui dat'n groter mate van [s]-distorsie voorkom by $\mathrm{Pp} 1$ ten spyte van normale en korter as normale duurwaardes. Proefpersoon 1 toon dus 'n groter mate van ruimtelike spraakklankdistorsie vir die [s]-klank as $\mathrm{Pp} 2$, terwyl Pp 2 weer'n groter mate van temporale spraakklankdistorsie vir die [s] vertoon. Die omvang en akkuraatheid van 
Isna Erasmus, Anita van der Merwe \& Emily Groenewald

artikulatoriese bewegings is dus moontlik by die serebellêre disartriesprekers aangetas ooreenkomstig die deurentyd by die intoriese simptome. Daar moet egter gehou word dat interpretasie van resultate in gedagte gewoontepatrone van spraakproduksie en selfs individuele die voorkoms van spelle in tandformasie 'n rol kan speel by

van spraakklankdistorsie.

ruimtelike sprakriese spreker toon' $n$ groter mate van serebellêre disartriaklanktorsie van die [s] as die akoestiese disartriesprekers, deurdat die omvang van normale en sergie heelwat wyer is as die omvang van die 'n Afname in serebellêre disartriesprekers (sien Figuur 5). ook voor, wat spektrone intensiteit van die uiting kom vermindering in die tografies waarneembaar is as 'n en dus die bepaling van dieidsgraad van die optekening bemoeilik baling van die gebied van ruis aansienlik akoestiese energie van voork 'n groot omvang van ing van kenolg wees van'n groter opening van konstriksie tydens [s]-produksie. Die verbaaldie fyn posisioner vertoon dus moontlik probleme met gekanaliseerde lugst van die artikulators om 'n sterk (1983) postuleer datroom te verseker. Kent en Rosenbek toriese posision dat probleme met akkurate artikulaverklaar kan word deur' $n$ verbale apraksie gedeeltelik waar ruimt word deur 'n teorie van motoriese kontrole space and time" (Kuimtelik-temporale skemata "or abstract goals in spraakproduksie aant \& Rosenbek, 1983, p.246) vir individuele motoriese preleer en gestoor word, sodat gespesifiseer word moontlik in stat by verbale apraksie is die spreker dus spesifikasies van nie-verbale beking en formulering van maar ervaar hy of -verbale bewegings (soos kou en sluk), spraakproduksie of die skte toegang tot die skemata van aantastingksie of die skemata is onbetroubaar weens skade het, kan daar. Aangesien Pp 3 ook subkortikale Van der Merwe (1994) ook op grond van die model van ruimtelike distor (1994) gespekuleer word dat hierdie Dis dus montorsie kan dui op programmeringsprobleme. omvang en rigting van die spreker probleme het om die beplande motoriese proweging te spesifiseer vanuit die uitgevoer moet word programme net voordat beweging rondom hierdie resul tate word verklarings en bespiegelings aan data oor [s]-produte word egter beperk deur'n gebrek sprekers, asook'n tekorsie by ander verbaal-apraktiese [s]-produksie by normale sprekers.

\section{Resultate en bespreking van formantmetings van
die [1]}

Figuur 6 illustreer die gemiddelde formantwaardes van F1, F2 en F3 van die [1]. Dit blyk dat formantwaardes van vanaf die normale fl]. Dit blyk dat die grootste afwyking die onderskeie diale formantwaardes voorkom by F3 van bewegingsaspekte diagnostiese groepe. Wat die ruimtelike diagnostiese groepe geen [1]-klank betref, toon beide spraakklankdistorsie geen akoesties identifiseerbare die perseptuele identifika formante verantwoordelik vir (Pickett, 1980).

Ruimtelike spraakklankdistorsie is geneem by formant drie vansprekers deurdat F3 drie van die serebellêre disartrieword soms geassosieer met die alveolêre afsluiting vir [l]-

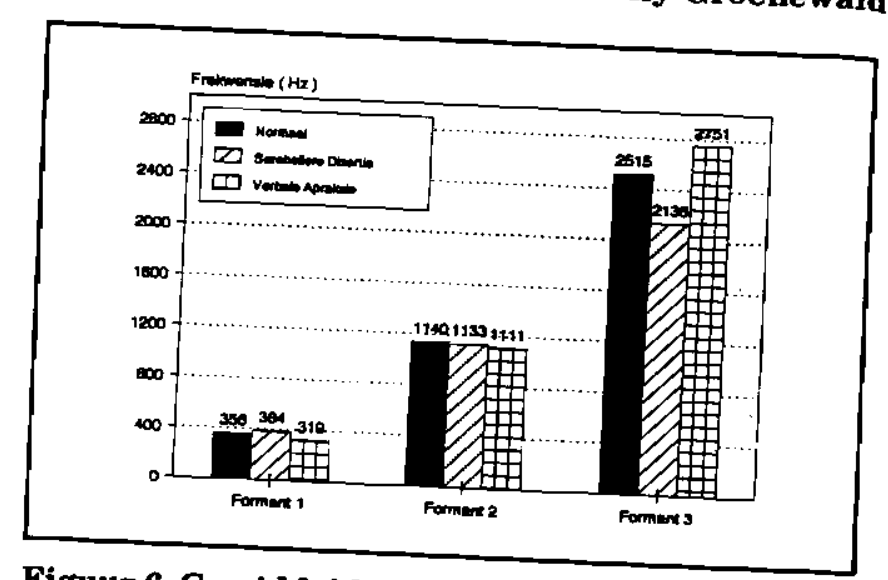

Figuur 6. Gemiddelde formantfrekwensiewaardes vir formante een, twee en drie van die [1] van die onderskeie diagnostiese groepe

produksie, sowel as allofoniese variasie van die [1] (Pickett 1980). In die literatuur is ongelukkig min bekend oor die fisiese resonansieveranderlikes geassosieer met F3 van die [1]. 'n Verlaging in F3 kan moontlik aanduidend van van die produksie van 'n swak alveolêre afsluiting, byna rif raak nie. So 'n war die tongpunt nie die alveolêre ding korreleer dus met vorige serebellêre disartriespreks aftuitingsklankproduksie by die weer eens dui op prekers in die huidige studie en kan programmering op probleme met die uitvoering of

kproduksie.

Die verbaal-apraktiese spreker toon in kontras met die serebellêre disartriesprekers eerder'n verhoging in F3 as 'n verlaging (sien figuur 6). Die F3-waarde van die verbaalnormale perkeker val egter steeds gering binne die normale perke en dui dus moontlik nie op ruimtelike F3-waarde distorsie nie. 'n Tbename in die gemiddelde F3-waarde van die [1] kan ook geassosieer word met kwaliteit van afsluitingsproduksie, maar 'n tekort aan beskikbare data oor normale F3-waardes en veranderlikes daarmee geassosieer, beperk die formulering van verklarings. 'n Opvallende by die verbaal-apraktiese waarneming van [1]-produksie swak energie oor 'n $n$ ise sprek is egter die neiging tot die gemiddelde drywingseide frekwensieomvang en dat formantpic drywingsdigtheidspektrum ook nie sterk verspreide omvantoon vir die [1] nie. So 'n s'wak en die plo omvang van energie kan dus die bepaling van groot F3-waarde by bemoeilik en ook die meting van 'n gevolg hê. Slegs by die verbaal-apraktiese spreker tot bevolg hê. Slegs beperkte data is in die literatuur verbaal-apraktieseande formantwaardes van die [l] by vind dat verbaal-aprakekers. Kent en Rosenbek (1983) met die [l] en [r]-apraktiese sprekers geneig is tot foute met die [l] en [r]-klanke deurdat die klanke soms uitgelaat formante mans mekar vervang word en dat die Soortgelyke waerneming aan mekaar gespasieer is. gemaak nie.

\section{ALGEMENE BESPREKING}

Afwykende SAT-waardes by die serebellêre disartriesprekers (veral $P$ p 2) kom voor as die resultaat van swak. alveolêre en vertraagde velêre afsluitingsproduksie en die resultate dui dus op afwykings in die omvang en 
akkuraatheid van artikulatoriese bewegings as sulks. Die ruimtelike bewegingsafwykings is moontlik die resultaat van onderliggende neuromotoriese probleme soos versteurde spiertonus en onwillekeurige bewegings en blyk ook verband te hou met die graad van serebellêre aantasting. Hierdie resultate kan afwykings in uitvoer en programmering van spraakbewegings reflekteer.

Die verbaal-apraktiese spreker daarteenoor is moontlik wel in staat tot akkurate artikulatoriese bewegings aangesien goeie kwaliteit alveolêre en velêre afsluitings voorkom by SAT-metings. Dit blyk dus asof probleme met die temporale beplanning van produksiekomponente van die [d] lei tot vertraagde stemgewing by die verbaalapraktiese spreker en nie afwykings in die bewegings self nie. Hierdie afleiding word bevestig deur bevindinge van Hardcastle (1987) aangaande bewegingsaspekte in die spraak van verbaal-apraktiese sprekers, naamlik: "The component gestures were thus normal spatially: what was disturbed was their temporal integration and their occurrence at inappropriate places" (Hardcastle, 1987, p.126).

Afwykings in konsonantduur van die [l] en die [s] is by die sprekers met serebellêre disartrie sowel as by die spreker met verbale apraksie opgemerk. Die serebellêre disartriesprekers toon verlengde duur ooreenkomstig die graad van aantasting moontlik weens probleme met die uitvoer van spraakbewegings. Die verbaal-apraktiese spreker toon 'n groter mate van temporale distorsie vir die [s] as die serebellêre disartriesprekers, intersillabe pouserings en langer duurwaardes vir KVKVK-eenhede as vir KVKV-eenhede, wat alles moontlik voorkom as die direkte gevolg van of as kompensasie vir'n onderliggende beplanningsprobleem. Die moontlikheid van 'n bydraende probleem in programmering is nie uitgesluit nie, veral in die lig van die subkortikale skade van die proefpersoon.

Die serebellêre disartriesprekers sowel as die verbaalapraktiese spreker toon ruimtelike distorsie van die [1] en [s] maar verskille in die aard en graad daarvan kom voor. Die verbaal-apraktiese spreker toon 'n groter mate van ruimtelike distorsie vir die [s] en toon ook 'n wyer omvang van ákoestiese energie as die serebellêre disartriesprekers. By die [l]-klank kom ' $n$ verhoging in F3 voor inteenstelling met 'n verlaging in F3 van die serebellêre disartriesprekers. Ruimtelike distorsie van die [s] en [1] kan probleme met die programmering en uitvoering van spraakbewegings by die serebellêre disartriesprekers reflekteer en kan dui op uitvalle met beplanning en programmering van spraakbewegings by die verbaalapraktiese spreker. Dis dus moontlik dat serebellêre disartriesprekers en die verbaal-apraktiese spreker se ruimtelike spraakklankdistorsie aanduidend kan wees van 'n ooreenstemming op die vlak van motoriese programmering.

Vanuit die studie is dit duidelik dat daar 'n behoefte bestaan aan ' $n$ omvattende teoretiese raamwerk of model van spraakproduksie waarbinne navorsingsdata geïnterpreteer kan word en waarbinne daar na oplossings vir bestaande vraagstukke rondom neuromotoriese spraakafwykings gesoek kan word. Daar bestaan ook'n behoefte aan verdere vergelykende navorsing binne die verskillende groepe neuromotoriese spraakafwykings om sodoende die kliniese onderskeid tussen simptome wat voorkom weens aantasting van ' $n$ beplannings-, programmerings- en uitvoerstadium van die spraakproduksieproses moontlik te maak.

\section{VERWYSINGS}

Allen, G.I. \& Tsukahara, N. (1974). Cerebrocerebellar communication systems. Physiological Reviews, 54(4), 957 997.

Baken, R.J. \& Daniloff, R.G. (1991). Readings in clinical spectrography of speech. San Diego: Singular Publishing Group and Kay Elemetrics.

Bannister, R. (1973). Brain's clinical neurology. 4de uitgawe, London : Oxford University Press.

Brooks, V.B. (1986). The neural basis of motor control. New York: Oxford University Press.

Brown, J.R., Darley, F.L. \& Aronson, A.E. (1970). Ataxic dysarthria. International Journal of Neurology, 7, 302-318.

Collins, M., Rosenbek, J.C., \& Wertz, R.T. (1983), Spectrographic analysis of vowel and word duration in apraxia of speech. Journal of Speech and Hearing Research, 26, 224230 .

Darley, F. Aronson, A.E. \& Brown, J.R. (1969a), Differential diagnostic patterns of dysarthria. Journal of Speech and Hearing Research, 12, 246-269.

Darley, F.L., Aronson, A.E. \& Brown, J.R. (1969b). Clusters of deviant speech dimensions in the dysarthrias. Journal of Speech and Hearing Research, 12, 462-469.

Freeman, F.J., Sands, E.S. \& Harris, K.S. (1978). Temporal coordination of phonation and articulation in a case of verbal apraxia : A voice onset time study. Brain and Language, 6, 106-111.

Gentil, M. (1990). Organization of the articulational system: Peripheral mechanisms and central coordination. In W.J. Hardcastle \& A. Marchal (Reds.) Speech production and speech modelling. The Netherlands: Kluwer Academic Publishers.

Gillmer, E. \& Van der Merwe, A. (1983). Die stemaanvangstyd van apraktiese en disartriese sprekers. Die SuidAfrikaanse Tydskrif vir Kommunikasieafwykings, 30, 3439.

Grunwell, P.A. \& Huskins, S. (1979). Intelligibility in acquired dysarthria - A neurophonetic approach : Three case studies. Journal of Communication Disorders, 12, 9-22.

Hardcastle, W.J. (1987). Electropalatographic study of articulation disorders in verbal apraxia. In J.H. Ryalls (Red.) Phonetic approaches to speech production in aphasia and related disorders. Boston: College-Hill Press.

Hardcastle, W.J., Morgan Barry, R.A. \& Clark, C.J. (1985). Articulatory and voicing characteristics of adult dysarthric and verbal dyspraxic speakers : An instrumental study. British Journal of Disorders of Communication, 20, 249270.

Itoh, M. \& Sasanuma, S. (1984). Articulatory movements in apraxia of speech. In J.C. Rosenbek, M.R. McNeil \& A.E.Aronson (Reds.) Apraxia of speech : Physiology, acoustics, linguistics, and management. San Diego: CollegeHill Press.

Itoh, M., Sasanuma, S., Tatsumi, I.F., Murakami, S., Fukusaki, Y \& Suzuki, T. (1982). Voice onset time characteristics in apraxia of speech. Brain and Language, 17, 193-210.

Kent, R.D. \& McNeil, M.R. (1987). Relative timing of sentence repetition in apraxia of speech and conduction aphasia. In J.H. Ryalls (Red.) Phonetic approaches to speech production in aphasia and related disorders. Boston: College-Hill Press.

Kent, R.D. \& Netsell, R. (1975). A case study of an ataxic dysarthric: cineradiographic and spectrographic observations. Journal of Speech and Hearing Disorders, 40, (1), 115-134.

Kent, R.D., Netsell, R. \& Abbs, J.H. (1979). Acoustic characteristics of dysarthria associated with cerebellar disease. Journal of Speech and Hearing Research, 22, 627. 648.

Kent, R.D. \& Rosenbek, J.C. (1982). Prosodic disturbance and neurologic lesion. Brain and Language, 15, 259-291.

Kent, R.D. \& Rosenbek, J.C. (1983). Acoustic patterns of apraxia of speech. Journal of Speech and Hearing Research, $26,231-249$.

Kertesz, A. (1982). Western aphasia battery. Toronto: GruneStratton. 
Kertesz, A. (1984). Subcortical lesions and verbal apraxia. In J.C. Rosenbek, M.R. McNeil \& A.E. Aronson (Reds.) Apraxia of speech: Physiology, acoustics, linguistics, and management. San Diego: College-Hill Press.

Klich, R.J., Ireland, J.V: \& Weidner, W.E. (1979). Articulatory and phonological aspects of consonant substitutions in apraxia of speech. Cortex, 15, 451-470.

Lisker, L. \& Abramson, A.S. (1964). A cross-language study of voicing in initial stops: Acoustic measurements. Word, 20, 384-422.

Odell, K., McNeil, M.R., Rosenbek, J.C. \& Hunter, L. (1990) Perceptual characteristics of consonant production by apraxic speakers. Journal of Speech and Hearing Disorders, $55,345-359$.

Odell, K., McNeil, M.R., Rosenbek, J.C. \& Hunter, L. (1991) Perceptual characteristics of vowel and prosody production in apraxic, aphasic and dysarthric speakers. Journal of Speech and Hearing Research, 34, 67-80.

Pickett, J.M. (1980). The sounds of speech communication : A primer of acoustic phonetics and speech production. Baltimore : University Park Press.

Sands, E.S., Freeman, F.J. \& Harris, K.S. (1978). Progressive changes in articulatory patterns in verbal apraxia : a longitudinal case study. Brain and Language, 6, 97-105.

Tyler, A.A. \& Waterson, T.L. (1991). VOT as a measurement of laryngeal function. Seminars in Speech and Language,
$12,(2), 131-141$

Van der Merwe, A., Uys, I.C., Loots, J.M. \& Grimbeek, R.J. (1988). Ouditief waarneembare foute by verbale apraksie: Aanduidings van die aard van die afwyking. Die SuidAfrikaanse Tydskrif vir Kommunikasieafwykings, 35, 4554.

Van der Merwe, A., Uys, I.C., Loots, J.M., Grimbeek, R.J. \& Jansen, L.P.C. (1989). Die invloed van sekere kontekstuele faktore op stemaanvangatyd, vokaalduur en uitingduur by verbale apraksie. Die Suid-Afrikaanse Tydskrif vir Kommunikasieafwykings, 36, 29-41.

Van der Merwe, A. (Vir publikasie 1994), A theoretical framework for the characterization of pathological speech sensorimotor control. In M.R. McNeil (Red). Clinical management of sensorimotor speech disorders. New York: Thieme Medical Publishers.

Wertz, R.T., LaPointe, L.L. \& Rosenbek, J.C. (1984). Apraxic of speech in adults: The disorder and its management. Orlando : Grune \& Stratton, Inc.

Zlatin, M.A. (1974). Voicing contrast : Perceptual and productive voice-onset time characteristics of adulta. The Journal of the Acoustical Society of America, 56, 981-994.

Zyski, B.J. \& Weisiger, B.E. (1987). Identification of dysarthria types based on perceptual analysis. Journal of Communication Disorders, 20, 367-378. 